\title{
VEGE INC.: USAHA YOGURT BERBAHAN DASAR SAYURAN DENGAN KONSEP KEMITRAAN
}

\author{
Submitted Date : \\ 24 April 2019 \\ Accepted Date : \\ 10 Mei 2019
}

\author{
Afandinata Wijaya \\ Universitas Ma Chung Malang \\ 111510003@student.machung.ac.id \\ Gian Avila Chandra \\ 111510051@student.machung.ac.id \\ Vivi Melia Hariono \\ Universitas Ma Chung Malang \\ 111510105@student.machung.ac.id \\ Yunita Pratiwi Saputra \\ Universitas Ma Chung Malang \\ 111510114@student.machung.ac.id
}

\section{Suggested Citation:}

Emamisaleh, K., Rahmani, K., \& Iranzadeh, S. 2018. Sustainable Supply Chain Management Practices and Sustainability Performance in the Food Industry. The South East Asian Journal of Management.

\section{Abstract:}

Vege Inc. is a start-up business engaged in the food and beverages sector with the main product, vegetable yogourt. Vege Inc. will work together with Sebaluh's village who are the business partner. All the process from collecting the raw materials from fresh cow milk and fresh vegetables - to the production process will be done in Sebaluh. There are two variants of vegetables yogourt that will be produced, original and less sugar. In the first until the fourth year business runs, Vege Inc. management will produce and sell 200 bottles per day with a selling price of $R p$ 8,000.- for each bottle. Meanwhile, from the financial statement projections and analysis of financial statement projections analysis, it was found that the BEP will occur on the 122nd day. It took 1 years and more than 4 months for the payback period, for Vege Inc. management to cover the investment planted. Thus we can know that Vege Inc. is feasible to run because it has a favorable projection and a relatively fast return period of investment.

Keyword : Partnership, Production Team, Vege Army, Vege Inc., Yogourt

\section{Abstrak:}

Vege Inc. adalah usaha start up yang bergerak di bidang food and beverages dengan produk utama yaitu yogurt sayuran. Vege Inc. akan bekerja bersama masyarakat Dusun Sebaluh yang merupakan mitra usaha. Seluruh bahan baku, mulai dari susu sapi dan sayuran segar hingga proses produksi akan dilakukan di Dusun Sebaluh. Terdapat dua varian yogurt sayuran yang diproduksi, yaitu original dan less sugar. Manajemen Vege Inc. akan memproduksi dan menjual sebanyak 200 botol per hari dengan harga jual sebesar Rp 8.000.- Sementara itu dilihat dari proyeksi laporan keuangan dan analisis proyeksi laporan keuangan, didapat bahwa BEP Vege Inc. akan terjadi pada hari ke-122. Diperlukan waktu 1 tahun lebih 4 bulan bagi Vege Inc. untuk dapat menutup investasi yang ditanam. Dengan demikian usaha Vege Inc. layak untuk dijalankan karena memiliki proyeksi yang menguntungkan dan jangka waktu pengembalian investasi yang relatif cepat.

Kata Kunci: Kemitraan, Tim Produksi, Vege Inc., Vege Army, Yogurt 


\section{Ringkasan Eksekutif}

Vege Inc. adalah usaha start up yang bergerak di bidang food and beverages dengan produk utama yaitu yogurt sayuran. Vege Inc. akan bekerja bersama masyarakat Dusun Sebaluh yang merupakan mitra usaha. Seluruh bahan baku, mulai dari susu sapi dan sayuran segar hingga proses produksi akan dilakukan di Dusun Sebaluh. Terdapat dua varian yogurt sayuran yang diproduksi, yaitu original dan less sugar. Segmentasi pasar untuk produk Vege Inc, dengan varian original adalah orang berusia 5-17 tahun sedangkan untuk varian less sugar adalah orang berusia 18 keatas. Strategi promosi yang diterapkan oleh manajemen Vege Inc. adalah dengan periklanan, penjualan personal, dan promosi penjualan. Tujuan pemasaran dari Vege Inc. adalah untuk membangun brand awareness dan meningkatkan loyalitas konsumen. Dalam upaya untuk membangun brand awareness, pemasaran akan dilakukan baik secara offline maupun online.

Demi kelancaran proses operasional, pada tahun pertama hingga keempat usaha berjalan Vege Inc. akan merekrut 4 orang karyawan yang terdiri dari 2 orang Vege Army dan 2 orang tim produksi. Sementara pada tahun kelima akan ditambahkan 2 orang Vege Army dan 2 orang tim produksi. Besarnya gaji sesuai dengan perjanjian kerja yang sudah disetujui dan ditanda tangani oleh kedua belah pihak, yaitu sebesar UMK Kabupaten Malang. Tidak hanya itu kesehatan dan keselamatan kerja diatur dalam sistem yang terintegrasi dengan sistem manajemen perusahaan Vege Inc. menaruh perhatian khusus terhadap keselamatan seluruh karyawannya baik yang tergabung dalam tim produksi maupun Vege Army.

Berdasarkan analisis kelayakan usaha, manajemen Vege Inc. harus memproduksi dan menjual sebanyak 200 botol per hari dengan harga jual sebesar Rp 8.000.- Sementara itu dilihat dari proyeksi laporan keuangan dan analisis proyeksi laporan keuangan, didapat bahwa BEP Vege Inc. akan terjadi pada hari ke-122. Diperlukan waktu 1 tahun lebih 4 bulan bagi Vege Inc. untuk dapat menutup investasi yang ditanam sebesar Rp 84.552.000,-. Nilai profitability index Vege Inc. adalah 3. ROI Vege Inc. setiap tahun mengalami peningkatan dengan ROI tahun pertama $-17,6 \%$ dan di tahun kelima $65,9 \%$. Begitu pula dengan ROA terjadi peningkatan dari tahun pertama hingga kelima, dari 4,9\% menjadi 18,4\%. Dengan demikian usaha Vege Inc. layak untuk dijalankan karena memiliki proyeksi yang menguntungkan dan jangka waktu pengembalian investasi yang relatif cepat.

\section{Latar Belakang}

Persaingan bisnis makanan dan minuman, khususnya minuman ringan membuat banyak produsen melakukan berbagai cara agar produk minuman ringan mereka dapat bersaing di pasaran. Banyak produsen yang menjual produk minuman ringan dengan menambahkan zat-zat yang berbahaya seperti zat pengawet, zat pemanis buatan, zat penguat rasa, dan zat pewarna yang tidak alami.Peluang yang bisa diambil dari kondisi tersebut adalah dengan menghadirkan produk makanan dan minuman ringan yang aman untuk dikonsumsi dan memberikan manfaat bagi kesehatan tubuh seperti produk Vege Inc.

Vege Inc. merupakan usaha yang memproduksi jenis-jenis minuman yang berbasis sayuran. Produk utamanya adalah minuman ringan olahan susu sapi dan sayuran yang cocok dikonsumsi dan bermanfaat bagi tubuh. Kota Batu dan Kota Malang serta sekitarnya terkenal dengan hasil bumi berupa sayuran dan buah-buahan serta susu sapi. Vege Inc. yang bahan-bahan dasar serta sumber daya manusianya diambil dari Dusun Sebaluh akan menerapkan konsep kemitraan dalam menjalankan proses produksi dan pemasarannya. Tim pendiri Vege Inc. sadar akan adanya potensi dalam mengolah susu sapi dan komoditas sayuran yang ada di Dusun Sebaluh, dan tim mengajak warga Dusun Sebaluh untuk menjadi mitra yang mampu menyuplai susu sapi serta sayuran segar. Vege Inc. juga menjadi produk minuman olahan yang cocok bagi orang yang tidak suka mengkonsumsi sayuran. Secara tidak langsung, dengan mengkonsumsi yogurt sayuran tersebut konsumen mendapatkan manfaat sayuran. Produk Vege Inc. dibuat dari bahan-bahan alami dan tanpa menggunakan bahan pengawet. 


\section{Visi, Misi dan Nilai Perusahaan}

Visi Vege Inc. adalah menjadi pioner usaha yogurt oleh-oleh khas Batu dan Malang yang bersifat home industry yang hadir di wilayah Batu dan Malang dan turut serta dalam perkembangan ekonomi masyarakat untuk kesejahteraan bersama.

Misi Vege Inc. adalah:

a. Memproduksi minuman ringan yang aman dan berkualitas tinggi.

b. Memperkenalkan produk susu fermentasi sebagai salah satu oleh-oleh khas Batu dan Malang secara luas.

c. Menjadikan petani sayuran, peternak sapi, dan masyarakat yang ada di Dusun Sebaluh sebagai mitra guna mengangkat perekonomian daerah.

d. Mengimplementasikan dan mendapatkan sertifikasi dan perizinan yang berlaku di Indonesia.

e. Menambah variasi produk dengan bahan dasar sayuran selain wortel.

Tujuan utama Vege Inc. adalah untuk membangun relasi dengan pelanggan, mitra kerja dan pemegang saham. Nilai-nilai yang menjadi dasar dalam menjalankan usaha Vege Inc. dan mencapai tujuan tersebut antara lain: higienis, kolaborasi, kepemimpinan dan tanggung jawab pribadi, kualitas, lingkundan dan keberlanjutan.

\section{Gambar 1. Logo Vege Inc}

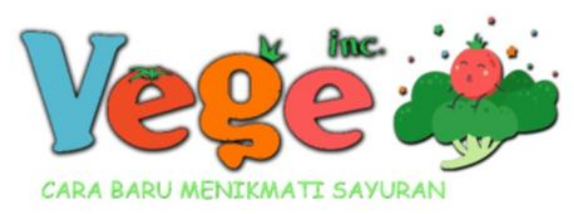

Nama merek Vege Inc. diambil dari kata serapan bahasa Inggris vegetable yang berarti sayuran, kata ini sesuai dengan produk Vege Inc. yang memiliki produk hasil olahan dari sayur. Sedangkan kata "Inc." merupakan singkatan dari Incorporation yang artinya adalah perusahaan.

Logo dari Vege Inc. merupakan bentuk tulisan dari nama perusahaan sendiri agar memudahkan konsumen untuk mengenali dan mengingat perusahaan. Logo Vege Inc. memiliki atribut berupa nama perusahaan yang disertai dengan gambar sayur brokoli dan tomat yang mengindikasikan jenis sayuran, selain itu pada bagian bawah terdapat tagline Vege Inc. yang menggambarkan keunikan dari perusahaan yaitu "Cara baru menikmati sayuran".

\section{Struktur Organisasi}

Struktur organisasi Vege Inc. dibedakan menjadi 2, yaitu struktur organisasi jangka pendek (jangka waktu 1-4 tahun) dan struktur organisasi jangka panjang (jangka waktu 5 tahun ke atas).

\section{Gambar 2. Struktur Organisasi}

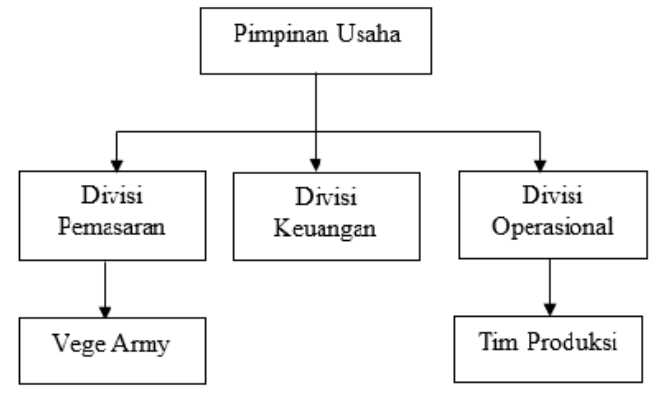

Vege Inc. akan dipimpin oleh seorang pimpinan usaha yang secara langsung membawahi 3 divisi, yaitu divisi pemasaran, divisi keuangan dan divisi operasional. Divisi pemasaran dan divisi operasional, masing-masing 
memiliki 2 orang karyawan, lalu pada tahun kelima akan ditambahkan masing-masing 2 orang karyawan lagi pada dua divisi tersebut.

\section{Jam Kerja Karyawan}

Jam kerja yang diterapkan oleh Vege Inc. sebagaimana disebutkan dalam Undang-Undang Republik Indonesia Nomor 13 Tahun 2003 tentang Ketenagakerjaan adalah 40 jam dalam 1 minggu untuk 6 hari kerja. Hari operasional kerja adalah mulai hari Senin hingga Sabtu. Karyawan akan bekerja full day pada hari Senin hingga Jumat dengan jam operasional kerja mulai pukul 08.00 - 16.00 WIB. Sementara itu, karyawan akan bekerja half day pada hari Sabtu dengan jam operasional kerja mulai pukul $08.00-13.30$ WIB.

\section{Pemutusan Hubungan Kerja (PHK)}

Pemutusan hubungan kerja dilaksanakan sesuai dengan Undang-Undang Republik Indonesia Nomor 13 Tahun 2003 tentang Ketenagakerjaan Pasal 161 ayat (1), yaitu apabila pekerja tidak mengindahkan dan menunjukkan perilaku yang berkualitas setelah yang bersangkutan diberikan surat peringatan pertama, kedua, dan ketiga secara berturut-turut.

Adapun ketentuan mengenai pemutusan hubungan kerja juga akan dicantumkan dalam kesepakatan kerja yang ditandatangani oleh kedua belah pihak. Selain itu pemutusan hubungan kerja juga dilakukan saat karyawan yang bersangkutan dinyatakan pensiun dan telah menyelesaikan kesepakatan kerja dalam jangka waktu yang telah disepakati bersama.

\section{Kesehatan dan Keselamatan Kerja (K3)}

Kesehatan dan keselamatan kerja diatur dalam sistem yang terintegrasi dengan sistem manajemen perusahaan. Manajemen Vege Inc. menaruh perhatian khusus terhadap keselamatan seluruh karyawannya, baik yang tergabung dalam tim produksi maupun Vege Army. Manajemen Vege Inc. juga akan mendaftarkan seluruh karyawan tetap untuk menerima BPJS Ketenagakerjaan, yang mana iuran per bulan untuk BPJS Ketenagakerjaan sudah termasuk dalam rincian upah yang diterima oleh karyawan setiap bulannya dan dibayarkan oleh pimpinan usaha Vege Inc. Manajemen Vege Inc. juga akan melakukan training pada saat penyambutan karyawan baru. Hal ini ditujukan agar karyawan mampu menangani kejadian-kejadian diluar dugaan yang terjadi selama jam operasional kerja.

\section{Segmenting}

Segmentasi pasar Vege Inc. didasarkan pada segmentasi demografi. Unsur demografi yang digunakan adalah unsur usia.

Tabel 1. Tabel Segmentasi Vege Inc.

\begin{tabular}{|c|c|c|}
\hline Dasar Segmentasi & $\begin{array}{c}\text { Identifikasi } \\
\text { Segmen }\end{array}$ & Karakteristik \\
\hline $\begin{array}{c}\text { Demografi berdasar } \\
\text { usia }\end{array}$ & $5-17$ tahun & $\begin{array}{c}\text { Memerlukan yogurt dengan kandungan protein } \\
\text { dan kalsium lebih banyak, rasa yang enak, tidak } \\
\text { suka mengonsumsi sayuran dan kemasan yang } \\
\text { menarik }\end{array}$ \\
\cline { 2 - 3 } & 18 tahun ke atas & $\begin{array}{c}\text { Memerlukan produk yang rendah lemak dan } \\
\text { gula, lebih mengutamakan nilai manfaat } \\
\text { daripada rasa, tidak terlalu mempertimbangkan } \\
\text { kemasan, suka dengan produk yang praktis. }\end{array}$ \\
\hline
\end{tabular}




\section{Targetting}

Vege Inc. menggunakan strategi differentiated marketing dalam memilih target pasar. Strategi differentiated marketing merupakan strategi pemasaran yang membedakan upaya pemasaran pada masing-masing kelompok konsumen (Assauri, 2013). Varian produk Vege Inc. original ditargetkan untuk kelompok konsumen usia 5 sampai 17 tahun sedangkan produk Vege Inc. less sugar ditargetkan untuk kelompok konsumen usia 18 tahun ke atas.

\section{Positioning}

Positioning dilakukan untuk membangun kesan atau image khusus suatu produk yang membedakan satu merek dari merek lainnya (Kotler, 2010). Vege Inc. merupakan produk yang menonjolkan nilai kesehatan. Vege Inc. ingin menunjukkan bahwa produknya merupakan produk yang berusaha untuk meningkatkan nilai kesehatan masyarakat sebagai barang subtitusi dari sayuran dan produk yang mendukung perekonomian masyarakat lokal dengan cara mengambil bahan baku langsung dari petani dan petani setempat di Dusun Sebaluh.

\section{Marketing Mix}

Marketing mix atau bauran pemasaran adalah strategi pemasaran yang dapat digunakan oleh manajemen untuk menentukan kesuksesan perusahaan dalam mengejar profit atau keuntungan maksimal. Strategi tersebut dapat dilakukan dengan cara-cara yang tergabung dalam konsep 4P, yaitu products, price, place, promotion (Emamisaleh, dkk, 2018).

\section{Product}

Kemasan produk Vege Inc. merupakan botol bening yang memiliki tinggi kemasan $14,5 \mathrm{~cm}$, diameter kemasan 6,5cm, dan isi bersih $250 \mathrm{ml}$. Label kemasan dari produk Vege Inc. terdiri dari logo Vege Inc., nomor customer service, komposisi produk, informasi perusahaan, nomor BPOM, tanggal kedaluarsa, isi bersih, cara penyimpanan, dan komposisi produk yang digunakan dalam satu botol Vege Inc.

Desain kemasan varian original didesain dengan warna yang lebih gelap dan berwarna mencolok yaitu warna oranye, sedangkan kemasan varian less sugar didesain dengan warna yang lebih terang yaitu warna putih kekuningan dengan tulisan "less sugar" sebagai pembeda.

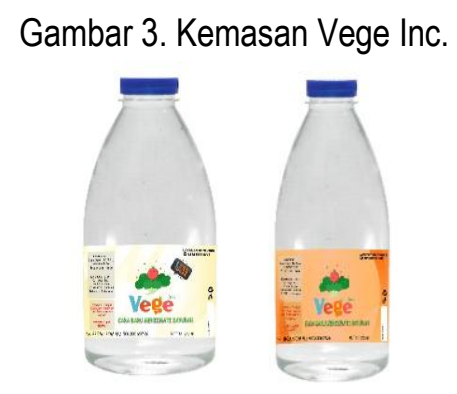

\section{Price}

Vege Inc. menetapkan harga yang cukup terjangkau agar dapat bersaing di pasar, hal ini dikarenakan Vege Inc. merupakan produk yang baru masuk di pasar dan belum dikenal oleh masyarakat. Vege Inc. menjual produknya dengan harga Rp 8.000,- per botol. Vege Inc. mampu menekan harga produknya karena Vege Inc. mendapatkan bahan baku langsung dari petani dan peternak sapi di Dusun Sebaluh.

\section{Place}

Pemasaran produk Vege Inc. dilakukan di seluruh daerah Kota Batu dan Kota Malang terutama di toko oleh-oleh dan toko-toko kelontong. Produk yang siap untuk didistribusikan akan dikumpulkan terlebih dahulu di kantor Vege Inc. 
Pendistribusian produk Vege Inc. secara langsung ke rumah-rumah dilakukan oleh tim Vege Army. Vege Army juga akan memasarkan produknya di toko-toko khas oleh-oleh dan toko-toko kelontong yang terletak di Kota Batu dan Malang Raya. Tim Vege Army akan memiliki rute distribusi yang dapat menjangkau seluruh calon konsumen di Kota Batu dan Malang Raya.

\section{Promotion}

Vege Inc. membangun brand awareness melalui media offline maupun online. Media offline yang digunakan berupa brosur-brosur yang disebarkan dan banner yang dipasang di toko-toko tempat oleh-oleh khas Batu dan Malang. Sedangkan untuk media online Vege Inc. memanfaatkan website, media sosial Facebook dan Instagram. Strategi yang digunakan untuk membangun brand awareness Vege Inc. adalah paid promote dan endorsement yang akan dilakukan melalui media-media online.

Brand awareness dari Vege Inc. dapat dinilai dari jumlah followers akun Instagram dan Facebook milik Vege Inc. Target followers pada tahun pertama adalah berjumlah 300 followers pada Instagram dan Facebook, dan meningkat sebesar 200 pada tahun-tahun berikutnya, sehingga pada akhir tahun kelima, Vege Inc. akan memiliki 1.200 followers.

Sales promotion yang pertama dilakukan oleh Vege Inc. adalah product bundling. Produk Vege Inc. akan dikemas dalam 1 bundle dengan masing-masing bundle berisi 10 botol produk Vege Inc. dengan harga Rp. 70.000,- per bundle.

\section{Ramalan Penjualan}

Ramalan penjualan pada tabel 2 menunjukkan bahwa terjadi peningkatan penjualan di setiap tahun dari total penjualan yogurt Vege Inc. Peningkatan penjualan sebesar $25 \%$ setiap tahunnya didasarkan pada prediksi keberhasilan promosi yang terus dilakukan oleh Vege Inc. dengan tujuan meningkatkan brand awareness, sehingga produk Vege Inc. semakin dikenal oleh masyarakat.

Tabel 2. Ramalan Penjualan Vege Inc.

\begin{tabular}{|l|l|l|l|}
\hline Tahun & $\begin{array}{l}\text { Penjualan } \\
\text { Per Tahun } \\
\text { (Botol) }\end{array}$ & $\begin{array}{l}\text { Penjualan } \\
\text { Per Bulan } \\
\text { (Botol) }\end{array}$ & $\begin{array}{l}\text { Penjualan } \\
\text { Per Hari } \\
\text { (Botol) }\end{array}$ \\
\hline 2019 & 72.000 & 6.000 & 200 \\
\hline 2020 & 129.600 & 10.800 & 360 \\
\hline 2021 & 201.600 & 16.800 & 560 \\
\hline 2022 & 216.000 & 18.000 & 600 \\
\hline 2023 & 432.000 & 36.000 & 1.200 \\
\hline
\end{tabular}

Tahun 2019 dan 2020 adalah tahun-tahun awal Vege Inc. dipasarkan, sehingga Vege Inc. memperkirakan 2 tahun pertama masa penjualan adalah tahun dimana Vege Inc. harus berhasil menembus pasar Kota Batu dan Kota Malang dengan giat mencari pelanggan sebanyak-banyaknya yang tersebar di berbagai daerah Kota Batu dan Kota Malang. Dalam 4 tahun tersebut diharapkan Vege Inc. telah menjadi minuman konsumsi sehari-hari rumah tangga di daerah Kota Batu dan Kota Malang. Pada tahun kelima diharapkan terjadi peningkatan penjualan sebesar $50 \%$ dari tahun sebelumnya, karena di tahun kelima tersebut Vege Inc. telah menambah jumlah karyawan dan juga meluaskan jalur distribusi ke daerah Kota Malang. 


\section{Proses Operasional}

Gambar 4. Proses Operasional Vege Inc.

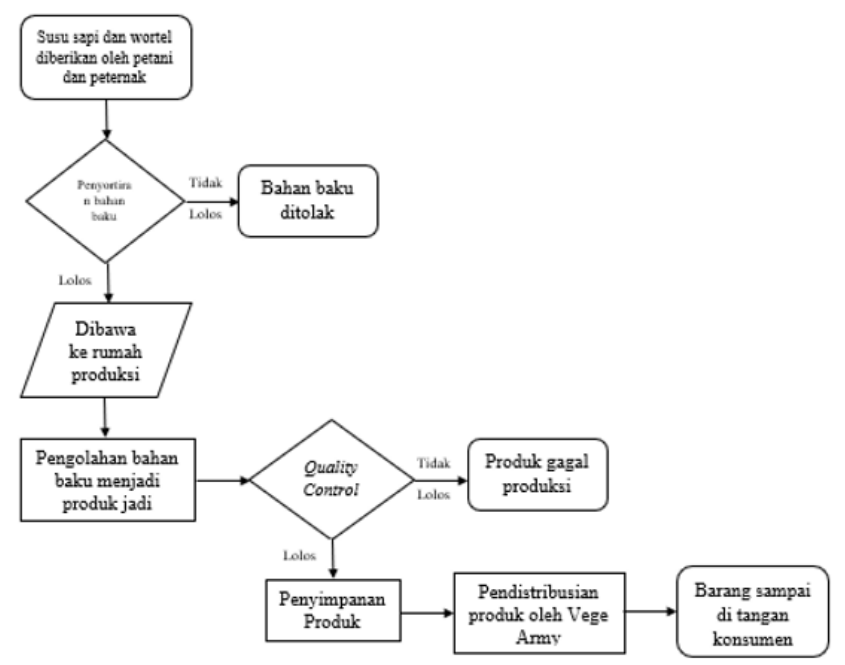

Dalam menjalankan operasional Vege Inc., memiliki dua macam lokasi operasi yaitu kantor dan rumah produksi. Masing-masing lokasi operasi harus memiliki jam operasional yang jelas untuk memudahkan sekutu aktif menjalankan fungsi controling terhadap tenaga kerjanya. Dalam operasionalnya, manajemen Vege Inc. akan memulai kegiatannya dari pengadaan bahan baku, proses produksi, quality control, penyimpanan produk hingga pendistribusian produk hingga sampai di tangan konsumen seperti terlihat pada Gambar 4.

\section{Penyediaan Bahan Baku}

Bahan baku yang dibutuhkan oleh Vege Inc. diperoleh dari petani sayur dan peternak sapi yang merupakan mitra kerja Vege Inc. yang berada di Dusun Sebaluh. Adapun standar kualitas susu sapi dan wortel yang dapat diterima oleh manajemen Vege inc. dari pemasok adalah sebagai berikut:

a. Susu Sapi

- Tekstur yang cair dan tidak terlalu kental seperti air yang berwarna putih.

- Tidak ada gumpalan (seperti santan yang pecah).

- Aroma creamy dan tidak berbau asam/tidak sedap.

- Rasa manis yang tidak terlalu kuat dan sedikit asin (creamy).

b. Wortel

- Wortel muda yang masih segar, tidak terdapat retakan ataupun lembek.

- Berwarna oranye terang. Kondisi ini menandakan bahwa wortel tersebut memiliki kandungan beta karoten yang lebih tinggi.

- Ukuran sedang, tidak terlalu kecil dan tidak terlalu besar dengan ujung lancip. Kondisi ini menandakan, lapisan kayu pada wortel tidak terlalu banyak sehingga teksturnya tidak keras dan lebih mudah untuk diolah.

Untuk meminimalisir kesalahan dari pemasok, manajemen Vege Inc. akan membuat perjanjian dengan peternak sapi dan petani sayuran jika pengantaran bahan baku terlambat. Manajemen Vege Inc. juga akan memiliki lebih dari 2 pemasok agar tidak terjadi kekurangan permintaan bahan baku. Apabila dari cadangan pemasok juga tidak dapat memenuhi kebutuhan bahan baku, maka akan ada denda yang diberikan kepada pemasok apabila suplai bahan baku terlambat dari jadwal yang sudah ditentukan. Adapun denda yang diberlakukan adalah $\mathrm{Rp} 369.230$,- untuk petani sayur dan $\mathrm{Rp} 256.730$,- untuk peternak sapi. 
Bahan pembantu lainnya seperti botol, gula pasir, dan biakan bakteri dapat diperoleh dengan mudah disekitar Kota Batu dan Kota Malang. Dalam mengatur persediaan produk, manajemen Vege Inc. menggunakan metode First In First Out (FIFO). Alasan dari pemilihan metode ini adalah karena Vege Inc. bergerak dalam bidang food and beverages dimana bahan baku dan produk yang dihasilkan memiliki umur yang relatif pendek sehingga produk dengan tanggal kedaluwarsa terdekat yang akan dijual terlebih dahulu untuk menghindari kerusakan produk yang dapat menyebabkan kerugian finansial.

\section{Rencana Kontinjensi Perusahaan}

Risiko-risiko yang dapat terjadi pada Vege Inc., seperti timbulnya kebakaran pada tempat produksi maupun di gudang, kerusakan kulkas yang berada pada kantor, adanya pesaing baru yang muncul dengan produk yang sama-sama memproduksi yogurt sayuran, pengantaran produk ke konsumen terlambat, permintaan jumlah susu dan wortel tidak bisa dipenuhi oleh pemasok bahan baku, dan bocornya resep yogurt wortel Vege Inc.

Pada rumah produksi akan disediakan tabung pemadam kebakaran, kompor akan dilengkapi selang dan regulator dengan kualitas yang baik untuk memperkecil kemungkinan terjadinya kebocoran gas dan ledakan tabung elpiji. Selain itu rumah produksi akan didesain sesuai dengan standar tempat kerja yang dimiliki manajemen Vege Inc. Tim produksi harus menggunakan sarung tangan dan juga masker untuk menjaga kualitas dan higienis produk yang dihasilkan. Hal ini dikarenakan, susu yang diolah harus higienis dan bebas dari bakteri patogen lainnya yang dapat mengganggu proses fermentasi. Vege inc. dalam usahanya akan menerapkan rahasia dagang.

Pelanggaran rahasia dagang perusahaan adalah apabila seseorang dengan sengaja mengungkapkan rahasia dagang, mengingkari kesepakatan atau mengingkari kewajiban tertulis atau tidak tertulis untuk menjaga rahasia dagang yang bersangkutan, dan seseorang memperoleh atau menguasai rahasia dagang dengan cara yang bertentangan dengan peraturan perundang-undangan yang berlaku.

\section{Aspek Keuangan}

Vege Inc. dalam merealisasikan bisnisnya, memerlukan modal sebesar Rp84.552.000,- yang akan didanai oleh 4 orang pendiri sebagai sekutu aktif dan juga 5 orang investor sebagai sekutu pasif. Modal awal Vege Inc. terdiri dari biaya yang diperlukan Vege Inc. untuk beroperasi selama 3 bulan. Persentase modal antara sekutu pasif dan aktif adalah 50\% : 50\% dengan besaran Rp 42.276.000,-. Asumsi keuntungan investor pada tahun II hingga V secara berturut-turut bila dilihat dari proyeksi laba/rugi adalah sebesar Rp1.954.177,-, Rp8.032.385,-, Rp15.913.580,-, Rp15.913.580,-, dan Rp28.343.992,-. Bila terdapat 5 investor, maka tiap investor akan mendapat pengembalian sebesar Rp10.848.827,-- dalam 5 tahun. Pada tahun pertama, keuntungan tidak akan dibagi demi mencapai kestabilan finansial.

Biaya yang harus dikeluarkan Vege Inc. setiap tahunnya adalah sebesar Rp376.214.000,-. Biaya yang diperkirakan akan menentukan besarnya HPP dan harga jual agar mendapat keuntungan. Adapun HPP Vege Inc. pada tahun I hingga tahun V adalah Rp6.029,-, Rp5.306,-, Rp4.148,- Rp4.108,-, dan Rp3.616,-. Sedangkan harga jual Vege Inc dari tahun I hingga V adalah Rp8.000,-, Rp8.800,-, Rp9.650,-, Rp10.650,-, dan Rp11.800,-- Kenaikan harga jual diasumsikan dipengaruhi inflasi sebesar $10 \%$ setiap tahunnya. Proyeksi saldo kas akhir Vege Inc. pada saat pendirian adaah $\mathrm{Rp}$ 204.206.500,-, dan pada tahun I hingga $V$ berturut-turut adalah Rp205.604.900,-, Rp209.377.900,-, Rp216.119.150,-, Rp226.570.713,-, dan Rp241.660.166,-. Saldo kas akhir yang selalu meningkat setiap tahunnya menandakan bahwa Vege Inc. memiliki kas yang cukup.

Laba/rugi Vege Inc. dari tahun I hingga V berturut-turut adalah -Rp148.639.680,-, Rp39.083.537,-, Rp160.647.693,-, Rp318.271.602,-, dan Rp566.879.838,-.Pada tahun I Vege Inc. mengalami rugi dikarenakan besarnya biaya pendirian yang dibayarkan untuk 5 tahun seperti sewa bangunan dan pembelian inventaris. Sementara di tahun II hingga V, Vege Inc. sudah mulai untung dan terus meningkat setiap tahunnya. Dari laporan laba/rugi dapat diamati bahwa operasional perusahaan berjalan dengan efisien. Modal akhir Vege Inc. pada tahun I hingga V berturut-turut adalah Rp84.552.000,-, Rp100.185.415,-, Rp164.444.492,-, Rp291.753.133,-, dan Rp518.505.068,-. Dari modal akhir tersebut, dapat diambil kesimpulan bahwa Vege Inc. mengalami kenaikan ekuitas dari transaksi keuangannya, menandakan bahwa Vege Inc. mengalami untung. 
Aset yang dimiliki oleh Vege Inc. adalah sebesar Rp302.376.500,-. Sementara total kewajiban dan ekuitas di periode pendirian adalah sebesar Rp193.652.750,-. Di tahun I hingga tahun $\mathrm{V}$ secara berutut-turut kewajiban dan ekuitasnya adalah sebesar Rp543.274.372,-, Rp1.127.594.980,-, Rp1.945.426.350,-, Rp3.046.610.960,-, dan Rp4.487.967.496,-- Untuk menilai profitabilitas rencana investasi, terdapat metode non konvensional yang dapat memperkirakan tolok ukur profitabilitas, yaitu Net Present Value (NPV), Profitability Index (PI), dan Internal Rate Return (IRR). Sedangkan dengan metode konvensional terdapat penghitungan Payback Period dan Rate of Return yang dalam prakteknya terdapat $R O A, R O E$, dan $R O I$.

Dari hasil perhitungan BEP, didapat bahwa titik impas Vege Inc. terjadi apabila Vege Inc. mendapat penghasilan dari penjualan sebesar Rp499.200.000,-. Dengan harga jual per botol Rp8.000,-, dapat diketahui bahwa Vege Inc. harus dapat mencapai penjualan sebanyak 73.492 botol yogurt dengan estimasi hari mencapai BEP adalah 122 hari (kurang dari satu tahun).NPV adalah alat ukur nilai waktu dari uang, sehingga Vege Inc. dapat menilai kelayakan usahanya. Dihitung menggunakan aplikasi financial calculators dengan estimasi cash flow yang diambil dari cash flow tahun pada tahun 0 Rp204.206.500,-, tahun I Rp205.604.900,-, tahun II Rp209.377.900,,tahun III Rp216.119.150,-, tahun IV Rp226.570.713,-, dan tahun V Rp241.660.166,-, serta BI rate sebesar 6\%, maka hasil NPV didapat sebesar 1.126.024.538,32. Hasil NPV >1 menandakan bahwa usaha Vege Inc. layak untuk direalisasikan karena dapat memberikan laba yang bernilai positif. Dari hasil perhitungan NPV, maka proyek Vege Inc. layak diterima dan dijalankan.

\section{Perhitungan Rasio Keuangan}

Profitability Index dihitung untuk mengetahui perbandingan nilai sekarang dengan nilai masa depan serta investasi yang disetor. Jika hasilnya <1 (Moritian, 2013), maka rancangan usaha tidak layak untuk dijalankan. PI Vege Inc. didapat dari nilai aliran kas masuk sebesar Rp241.660.166,- dibagi dengan nilai investasi Rp84.552.000,, hasilnya adalah 3. Sehingga dapat disimpulkan bahwa rancangan usaha Vege Inc. layak untuk dijalankan karena angka 3 tersebut melambangkan kemampuan investasi Vege Inc. dalam menghasilkan profit.

Payback period adalah rentang waktu yang dibutuhkan oleh pendapatan bersih suatu investasi untuk menutup biayanya. Hasil payback period dinyatakan sebagai ekspektasi jumlah tahun yang dibutuhkan untuk memperoleh kembali investasi awal. Semakin singkat payback period sering digunakan sebagai indikator tingkat risiko sebuah proyek (Brigham \& Houston, 2013). Dari hasil perhitungan payback period, maka dapat disimpulkan bahwa lama investasi tertutupi oleh keuntungan yang dibagikan oleh Vege Inc. termasuk cepat, yaitu 1 tahun lebih 4 bulan. Sehingga bagi para investor, pengembalian investasi yang cepat seperti Vege Inc, terlihat lebih menjanjikan.

ROI Vege Inc. setiap tahun mengalami peningkatan dengan ROI tahun pertama $-17,6 \%$ dan di tahun kelima $65,9 \%$. Begitu pula dengan ROA terjadi peningkatan dari tahun pertama hingga kelima, dari 4,9\% menjadi $18,4 \%$. Sementara IRR Vege Inc. didapat sebesar $12 \%$. Dari hasil IRR yang lebih tinggi daripada bunga bank, maka investor akan lebih memilih berinvestasi di Vege Inc. daripada menabung atau mendepositkan di bank.

\section{Daftar Pustaka}

Assauri, Sofjan. 2013. Manajemen Pemasaran. Jakarta: Rajawali Pers.

Brigham, F. \& Houston, F. 2013. Dasar-Dasar Manajemen Keuangan. Edisi 11 Buku 2. Jakarta: Salemba Empat. Emamisaleh, K., Rahmani, K., \& Iranzadeh, S. 2018. Sustainable Supply Chain Management Practices and Sustainability Performance in the Food Industry. The South East Asian Journal of Management.

Kotler, P. 2010. Manajemen Pemasaran Edisi 13. Jakarta: Erlangga.

Moritian, D. I. 2013. Analisis Kelayakan Investasi dan Monitoring Usaha Budidaya Ikan Bandeng secara Intensif

Berbasis Web di Sidayu Kabupaten Gresik. Jurnal Sistem Informasi.

Undang-Undang Republik Indonesia Nomor 13 Tahun 2003 tentang Ketenagakerjaan 